\title{
Peningkatan Kapasitas Kader Perlindungan Anak Terpadu Berbasis Masyarakat (PATBM) di Desa Natar Kecamatan Natar Kabupaten Lampung Selatan
}

\author{
Sri Suastuti *, Elman Eddy Patra, Kisti Artiasha \\ IImu Hukum, Universitas Lampung, Bandar Lampung, 35145, Lampung, Indonesia
}

\begin{abstract}
Abstrak.
Kegiatan Pengabdian Desa Binaan tentang Peningkatan Kapasitas Kader Perlindungan Anak Terpadu Berbasis Masyarakat (PATBM) di Desa Natar Kecamatan Natar Kabupaten Lampung Selatan dilaksanakan sejak bulan Maret sampai dengan September 2020 dengan sasaran kegiatan Kader PATBM Desa Natar yang berjumlah 20 orang dan calon kader yang merupakan perwakilan 11 Dusun yang ada di Desa Natar sebanyak 30 orang. Sejak tahun 2016 Desa Natar telah memiliki Kelompok Kader Perlindungan Anak Terpadu Berbasis Masyarakat (PATBM) yang telah mengikuti pelatihan kader baik di tingkat kabupaten maupun provinsi. Dari pendekatan yang kami lakukan secara individual dengan kader PATBM sebagai mitra sasaran kegiatan, dapat diketahui bahwa mereka sebagai bagian dari masyarakat telah berpartisipasi untuk melaksanakan tanggungjawab dan ikut mengupayakan perlindungan kepada anak untuk mencegah terjadinya kekerasan terhadap anak, namun disatu sisi mereka belum memiliki bekal pemahaman yang memadai tentang perlindungan anak, sehingga perlu dilakukan edukasi tentang hal itu. Disisi lain para kader juga memiliki kendala komunikasi dengan pihak Pemerintah Desa karena adanya peralihan jabatan yang pada akhirnya berpengaruh terhadap aktivitas kader PATBM. Kegiatan pengabdian ini dilakukan dengan cara memberikan bimbingan teknis dan konsultasi bagi Kader PATBM secara mandiri maupun kelompok baik di sekretariat PATBM maupun di Kampus Unila, dan pemberian materi secara umum yang diikuti oleh baik kader, calon kader maupun tokoh masyarakat di Aula Kantor Desa Natar pada 18 September 2020. Melalui kegiatan pengabdian ini Tim memberikan materi tentang perlindungan anak dan juga pentingnya PATBM, serta membantu memfasilitasi para kader PATBM untuk melakukan konsolidasi dengan pihak Pemerintah Desa dalam upaya pembinaan kader PATBM di Desa Natar.
\end{abstract}

Kata kunci.

PATBM, Perlindungan Anak, Natar Lampung Selatan.

* Corresponding author: tutiunila@gmail.com

Received 16 November 2020; Received in revised form 27 November 2020; Accepted 7 December 2020

Available online 24 December 2020

Lembaga Penelitian dan Pengabdian Kepada Masyarakat

Universitas Lampung 


\section{PENDAHULUAN}

Merebaknya berbagai kasus kekerasan anak tentu saja memprihatinkan kita semua. Keluarga sebagai institusi utama dalam perlindungan anak ternyata belum sepenuhnya mampu menjalankan peranannya dengan baik. Terdapat 4.116 kasus kekerasan terhadap anak sepanjang Tahun 2020 [1]. Kasus perceraian, disharmoni keluarga, keluarga miskin, perilaku ayah atau ibu yang salah, pernikahan sirri, dan berbagai permasalahan lainnya menjadi salah satu pemicu terabaikannya hak-hak anak dalam keluarga.

Ironisnya lagi, dalam institusi sekolah juga kerap terjadi tindak kekerasan maupun diskriminasi pendidikan pada anak. Demikian pula pada institusi sosial lainnya seperti yayasan/panti, nampak masih belum sama dalam memaknai kepentingan terbaik bagi anak. Bahkan pada penanganan anak yang berhadapan hukum, hak-hak anak masih perlu terus mendapatkan perhatian. Pada kenyataannya, berbagai persoalan pelanggaran hak anak kerap masih terjadi dan dianggap biasa oleh masyarakat kita, bahkan kalau diperkirakan cenderung meningkat seiring dengan meningkatnya masalah kritis seperti kemiskinan, ketidakadilan, kerawanan bencana baik bencana alam maupun bencana sosial, akses pornografi dan pornoaksi, disintegrasi bangsa, sindikat perdagangan narkoba dan sebagainya.

Berita dari berbagai media baik media cetak, online maupun elektronik terhadap maraknya kasus tindakan kekerasan pada anak maupun anak yang berhadapan dengan hukum merupakan informasi yang tidak dapat disangkal bahwa kasus-kasus tersebut sering menghiasi pemberitaan di media massa. Belum lagi kasus yang tidak terungkap, karena luput dari pemberitaan media atau memang sama sekali tidak ada yang mengetahui maupun melaporkan tentang pelanggaran terhadap hak anak tersebut.

Hal tersebut bertentangan dengan Konvensi Hak Anak Tahun 1989 dan Undang-Undang Dasar Republik Indonesia 1945, yang mengatur hak untuk bermain; hak untuk mendapatkan pendidikan; hak untuk mendapatkan perlindungan; hak untuk mendapatkan nama (identitas); hak untuk mendapatkan status kebangsaan; hak untuk mendapatkan makanan; hak untuk mendapatkan akses kesehatan; hak untuk mendapatkan rekreasi; hak untuk mendapatkan kesamaan; dan hak untuk berperan dalam pembangunan.

Dalam Undang Undang Nomor 35 Tahun 2014 tentang Perlindungan Anak dinyatakan, bahwa perlindungan anak bukan hanya menjadi tanggungjawab Pemerintah, tetapi juga tanggungjawab keluarga dan masyarakat. Peran masyarakat salah satunya dapat diwakili oleh anak-anak muda atau kader. Kader merupakan anggota masyarakat yang diutus oleh desa untuk mewakili masyarakat mengikuti pelatihan Perlindungan Anak Terpadu Berbasis Masyarakat (PATBM) yang merupakan program Kementrian Pemberdayaan Perempuan dan Perlindungan Anak.

Kader memiliki potensi apabila digerakan secara sistematis yang akan berkontribusi positif dalam pencegahan penanganan maupun rujukan kasus kekerasan anak di desa. Dari pendekatan yang dilakukan secara individual dengan mitra sasaran kegiatan yaitu para kader PATBM Desa Natar, dapat diketahui bahwa sebagai bagian dari masyarakat para kader ini juga sudah melaksanakan tanggungjawab untuk mengupayakan perlindungan kepada anak guna mencegah terjadinya kekerasan terhadap anak, namun disatu sisi mereka belum memiliki bekal pemahaman yang memadai tentang perlindungan anak khususnya tentang kekerasan terhadap anak dan upaya pencegahannya, serta ketentuan yang terkait dengan perlindungan anak, sehingga perlu dilakukan edukasi tentang hal itu. Untuk itu kami memandang perlu untuk melakukan kegiatan yang kami kemas dalam judul "Peningkatan Kapasitas Kader Perlindungan Anak Terpadu Berbasis Masyarakat (PATBM) di Desa Natar Kecamatan Natar Kabupaten Lampung Selatan".

\section{METODE}

Metode penerapan Iptek yang digunakan dalam pengabdian kepada masyarakat ini adalah berupa melakukan pretest dan posttest dalam bentuk tanya jawab dan melihat hasil pekerjaan atau tugas yang diberikan oleh tim dengan cara memberikan soal pretest kepada 
50 responden peserta kegiatan. Selanjutnya bimbingan teknis dan konsultasi yang dilakukan oleh ketua kelompok kader PATBM tentang beberapa hal seperti masalah kelembagaan, kerjasama dengan Pemerintah Desa, pembinaan kader, dan lain lain. Selanjutnya tim juga melakukan koordinasi dan diskusi awal dengan Kepala Desa, kemudian dilanjutkan dengan pemberian materi yang berkaitan dengan perlindungan anak.

\section{HASIL DAN PEMBAHASAN}

Perlindungan Anak Terpadu Berbasis Masyarakat (PATBM) adalah sebuah gerakan dari jaringan atau kelompok warga pada tingkat masyarakat yang bekerja secara terkoordinasi untuk mencapai tujuan perlindungan anak. PATBM merupakan inisiatif masyarakat sebagai ujung tombak untuk melakukan upayaupaya pencegahan dengan membangun kesadaran masyarakat agar terjadi perubahan pemahaman, sikap dan prilaku yang memberikan perlindungan kepada anak.

PATBM merupakan sumbangan masyarakat yang sangat berarti bagi perlindungan anak di Indonesia ini, karena melalui PATBM bisa dibudayakan norma sosial dan budaya yang melindungi anak, memperkuat ketrampilan orang tua dalam pengasuhan anak, melatih anak agar bisa melindungi dirinya sendiri dari kemungkinan kekerasan yang bisa terjadi serta masyarakat mampu untuk mengenali dan menanggapi dengan cepat jika terjadi kekerasan. Melalui PATBM, masyarakat diharapkan mampu mengenali, menelaah, dan mengambil inisiatif untuk mencegah dan memecahkan permasalahan kekerasan terhadap anak yang ada di lingkungannya sendiri.

Banyak pihak yang bisa diajak untuk mengembangkan PATBM di Desa, yaitu:

1. Dari Internal Desa: Kepala Desa, Perangkat Desa, Tokoh Adat, Tokoh Agama, Tokoh Masyarakat atau masyarakat lain yang bisa dan bersedia ikut mengembangkan PATBM.

2. Dari Eskternal Desa: Individu atau Lembaga yang mempunyai kepedulian terhadap perlindungan anak.

Kader PATBM memiliki tugas untuk mengenalkan PATBM dan menggerakkan partisipasi warga untuk ikut menjadi kader dalam kegiatan ini, serta menggalang dukungan (material maupun non-material termasuk sumbangan pemikiran) untuk pelaksanaan kegiatankegiatan PATBM. Untuk itu peningkatan kapasitas Kader PATBM sangat penting.

Kemampuan Kader PATBM diperkuat melalui pelatihan-pelatihan atau kegiatan pengembangan kapasitas lainnya (seperti melalui pelayanan konsultasi dan proses pendampingan oleh fasilitator, penyertaan dalam forum pertemuan/seminar/diskusi yang berkenaan dengan perlindungan anak, pertukaran pengalaman) [4]. Dalam Kamus Besar Bahasa Indonesia, arti kata pelatihan merupakan proses, cara, perbuatan melatih; kegiatan atau pekerjaan melatih [5]. Selain itu pengertian pelatihan adalah suatu proses yang meliputi serangkaian tindak (upaya) yang dilaksanakan dengan sengaja dalam bentuk pemberian bantuan yang dilakukan oleh tenaga professional kepada tenaga kerja dalam satuan waktu tertentu guna meningkatkan efektivitas dan produktivitas dalam suatu organisasi [6].

Kader dapat melakukan berbagai bentuk kampanye yang dapat dilakukan antara lain melalui media (leaflat, kartun, foto atau film), dialog interaktif, talkshow, seminar, atau kampanye yang dipadukan dengan kegiatan seni atau olah raga atau bazaar sehingga menarik perhatian, menggugah dan membangun kepedulian. Kegiatan promosi tersebut juga harus disertai dengan cara-cara persuasif yang dapat meyakinkan masyarakat sehingga membangun kepercayaan masyarakat terhadap PATBM. Penyeberluasaan manfaat PATBM dalam mencegah dan mengatasi kekerasan terhadap anak dan ceritacerita keberhasilan dapat digunakan untuk meyakinkan dan membangun kepercayaan untuk menggerakan pemanfataan secara meluas.

Pada tahap awal perwakilan aktivis akan diberi pelatihan PATBM (yang dilengkapi dengan teknik-teknik pengelolaan program dan teknik-teknik intervensi dalam perlindungan anak) oleh fasilitator dan/atau pendamping dari provinsi, untuk selanjutnya disebarkan ke 
para aktivis lainnya. Mereka juga dapat memperoleh pelatihan-pelatihan yang lebih menguatkan dan mengembangkan kemampuan mereka terutama dalam teknik-teknik intervensi [7].

Kegiatan pembinaan dan pelatihan PATBM ini bertujuan untuk meningkatkan rasa kepedulian, pengetahuan dan keterampilan masyarakat yang tergabung dalam gerakan PATBM untuk melakukan upaya pencegahan dan penanganan terkait isu anak berhadapan dengan hukum. Selain itu untuk mengembangkan mekanisme pelibatan Aktifis PATBM serta anak dan orang muda agar mampu mendesimansikan ke aktor-aktor strategis, mendidik mereka agar memiliki keterampilan yang cukup dalam menangani permasalahan eksploitasi anak.

Hasil evaluasi awal kegiatan terhadap pelaksanaan penyuluhan, dapat dikemukakan bahwa pengetahuan peserta tentang materi yang diberikan tergolong rendah. Hal ini dapat diketahui dari evaluasi awal kegiatan yang dilakukan melalui pre-test; pada awal kegiatan dalam bentuk tanya jawab dan melihat hasil pekerjaan atau tugas yang diberikan oleh tim dengan cara memberikan soal pretest kepada 50 responden peserta kegiatan.

Tabel 1. Hasil rekapitualasi evaluasi awal tingkat pengetahuan peserta tentang materi yang diberikan.

\begin{tabular}{ccccc}
\hline No & Interval & Responden & Persentase & Kategori \\
\hline 1 & $30-50$ & 40 & 80 & Rendah \\
2 & $51-70$ & 10 & 20 & Sedang \\
3 & $71-90$ & 0 & $0 \%$ & Tinggi \\
\hline & Jumlah & $\mathbf{5 0}$ & & \\
\hline
\end{tabular}

Berdasarkan hasil pre-test diketahui bahwa sebagian besar responden (80\%) memiliki tingkat pengetahuan dengan kategori rendah, sedangkan sebagian responden (20\%) memiliki tingkat pengetahuan dalam kategori sedang. Tingkat pengetahuan rendah yang dimiliki oleh para responden karena diakibatkan rendahnya informasi dan pengetahuan yang dimiliki. Pada akhir kegiatan dilakukan post-test kepada para peserta kegiatan terhadap semua materi yang disampaikan, maka dapat disimpulkan pengetahuan para peserta tentang perlindungan anak meningkat.

Setelah dilakukan pre-test, maka narasumber menyampaikan materi antara lain yang bersumber dari Undang-Undang Perlindungan Anak, Hak dan kewajiban serta tanggungjawab mereka dalam Perlindungan Anak, dan Perlindungan Anak Terpadu Berbasis Masyarakat. Kemudian dilanjutkan dengan sesi diskusi. Pada saat diskusi peserta dengan antusias mengikuti secara cermat. Meskipun disadari dalam beberapa segi peserta masih banyak mengalami kesulitan karena keterbatasan informasi, pemahaman dan pengetahuan mengenai perlindungan anak, namun dengan segala keterbatasan kemampuan dan sarana prasarana para peserta tetap bersemangat mengikuti penyuluhan.

Setelah dilakukan pretest, penyampaian materi dan motovasi, hingga diskusi, selanjutnya dilakukan kegiatan post-test, yaitu evalausi akhir saat materi yang di ajarkan pada hari pelaksanaan telah diberikan yang mana seorang fasilitator memberikan post-test dengan maksud apakah peserta sudah mengerti dan memahami mengenai materi yang baru saja diberikan pada hari pelaksanaan.

Tabel 2. Hasil post-test peserta Pelatihan.

\begin{tabular}{ccccc}
\hline No & Interval & Responden & Persentase & Kategori \\
\hline 1 & $30-50$ & 8 & $16 \%$ & Rendah \\
2 & $51-70$ & 36 & $72 \%$ & Sedang \\
3 & $71-90$ & 6 & $12 \%$ & Tinggi \\
\hline & Jumlah & $\mathbf{5 0}$ & & \\
\hline
\end{tabular}

Pada akhir kegiatan ini dapat dilihat ada peningkatan yang sangat signifikan dimana ada $6(12 \%)$ responden yang mendapatkan kategori tertinggi, 36 (62\%) responden mendapatkan kategori sedang dan 8 (16\%) mendapatkan kategori rendah. Kegiatan ini dianggap berhasil karena ada perbedaan nyata pengetahuan dan keterampilan sebelum dan sesudah kegiatan pengabdian dilakukan, dimana para peserta telah mampu memberikan jawaban seputar perlindungan anak yang sebelumnya kurang dipahami. Dengan demikian dapat dilihat adanya peningkatan yang berarti dan signifikan dari peserta 
dalam memahami perlindungan anak.

Faktor pendukung kegiatan pengabdian masyarakat tentang perlindungan anak dapat dilaksanakan dengan baik karena didukung oleh:

1. Apresiasi, kemauan, minat dan perhatian yang cukup besar dari peserta dan tim baik sebelum, dan sesudah Pelatihan.

2. Rasa ingin tahu peserta sangat besar karena materi perlindungan anak belum pernah didapat sebelumnya.

3. Peserta bersedia meluangkan waktu sepenuhnya, karena keingintahuaan tentang masalah perlindungan anak.

4. Para kader PATBM yang hadir cukup membantu untuk ikut memberikan motivasi kepada peserta yang lain.

5. Kepala Desa dan para kader PATBM tetap mengharapkan adanya pendampingan berkelanjutan dari Universitas Lampung untuk menjadi mitra dalam pelaksanaan PATBM di Desa Natar.

\section{KESIMPULAN}

Kegiatan pembinaan dan pelatihan PATBM ini bertujuan untuk meningkatkan rasa kepedulian, pengetahuan dan keterampilan masyarakat yang tergabung dalam gerakan PATBM untuk melakukan upaya pencegahan dan penanganan terkait isu anak berhadapan dengan hukum. Kegiatan peningkatan kapasitas Kader PATBM berhasil dilakukan di Desa Natar, Kecamatan Natar, Kabupaten Lampung Selatan. Kegiatan tersebut diisi dengan melakukan evaluasi awal atau pre-test kepada peserta, dilanjutkan penyampaian materi dan motivasi, selanjutnya dilakukan diskusi, dan diakhiri dengan evaluasi akhor atau post-test.

\section{DAFTAR PUSTAKA}

[1] https://www.suara.com/news/2020/08/24/105850/miris-sepanjang-2020-ada-4116-kasus-kekerasanterhadap-anak.

[2] Kementerian PPPA, Buku Saku Aktivis Kader Perlindungan Anak Terpadu Berbasis Masyarakat (PATBM), Jakarta, Kementerian Pemberdayaan Perempuan dan Perlindungan Anak, 2017, hlm. 3.

[3] Kementerian PPPA, Pedoman Perlindungan Anak Terpadu Berbasis Masyarakat (PATBM), Kementerian PPPA, Jakarta, 2016, hlm. 88.

[4] https://kbbi.web.id/pelatihan

[5] https://repository.widyatama.ac.id/xmlui/bitstream/handle/123456789/7584/Bab\%202.pdf?sequence=10

[6] https://www.kemenpppa.go.id/lib/uploads/slider/98dff-pedoman-patbm.pdf 